\title{
EFFICACY OF SYNTHETIC INSECTICIDES AGAINST THRIPS, THRIPS TABACI IN ONION
}

\author{
SWAGATIKA MISRA \& JOHNSON WAHENGBAM \\ School of Agriculture, Department of Entomology, Lovely Professional University, \\ G.T. Road, Phagwara, Punjab
}

\begin{abstract}
A field experiment was conducted to evaluate the efficacy of different synthetic insecticides, including organophosphates, pyrethroids and phenyl parasols, against onion thrips at agricultural farm, Lovely Professional University, Phagwara, Punjab, India, during August 2016 to January 2017. The incidence of thrips, T. tabaci on the plants treated with profenofos 50EC @625g a.i, was the most effective insecticide (1.65/3 leaves) with 57.40 per cent reduction in thrips population, compared to the mean of untreated check (3.89/3 leaves).

KEYWORDS: Profenophos 50EC, Lambda Cyhalothrin 2.5 EC, Fipronil 5SC and Quinalphos 25EC, Thrips \& Onion
\end{abstract}

Received: Aug 11, 2017; Accepted: Aug 26, 2017; Published: Sep 02, 2017; Paper Id.: IJASROCT201715

\section{INTRODUCTION}

Onion (Allium cepa L.) is an important tropical and the edible bulbous crop in India. India is the second largest producer of onion in the world next to China, with an estimated production area of 9.59 lakh ha with a production of 163.09 lakh tons and productivity of 17.01 tons/ha (FAO, 2012). Onions are best cultivated in fertile soils that are well-drained. The seeds are sown in raising nursery beds, during Kharif season (May- September), late kharif season (August- February) and Rabi season (October- April), after 45 days of nursery sowing, the seedlings are transferred to the main plot. Onions are harvested at 50\% neck fall stage, which is an indication of maturity and it decides the longevity of onions as bulbs in storage conditions. This crop is generally grown throughout the country, but especially in the states of Maharashtra, Uttar Pradesh, Odisha, Gujarat, Madhya Pradesh, Rajasthan, Punjab, Haryana, Uttarakhand, Jammu \& Kashmir, Bihar, Andhra Pradesh and Karnataka. This crop is ravaged by many insect pests, during different crop growth stages which cause considerable losses in yield. Apart from reduction in crop yield, insect pests also posses harmful effects during harvesting, post harvesting, processing and marketing stages, which lowers the quality and export potential of crop that significantly causes economic loss. It also alters the cropping pattern and also affects the local and export markets. Major insect pests infesting onion are thrips (Thrips tabaci Lindeman), onion maggot (Delia antique), red spider mite, (Tetranychus cinnabarinus), cutworms (Spodoptera litura) and head borer (Helicoverpa armigera).

Amongst these insect pests, onion thrips, Thrips tabaci (Thysanoptera: Thripidae), has become a global pest of increasing concern in commercial onion, because of its ability to transmit plant viruses and frequency of producing more generations at high temperatures. T. tabaci feeds directly on leaves, causing blotches and premature senescence, as well as distorted and undersized bulbs. T. tabaci can cause yield loss $>50 \%$ (Montano et al., 2010) but can be even more problematic, when it transmits iris yellow spot virus. IYSV symptoms include 
straw-colored, dry, tan, spindle or diamond shaped lesions on the leaves and scapes of onion plants and can cause yield loss up to $100 \%$.

\section{MATERIALS AND METHODS}

A field experiment was conducted to study the efficacy of different synthetic insecticides, against onion thrips at agricultural farm, Lovely Professional University, Phagwara, Punjab, India during August 2016 to January 2017. In this study, the synthetic insecticides, Profenophos 50EC (375g. a.i), Profenophos 50EC (500g. a.i), Profenophos 50EC (625g. a.i), Lambda Cyhalothrin 2.5 EC @ 15 g.a.i, Fipronil 5SC @ 50 g.a.i and Quinalphos 25EC @ 300 g a.i. were evaluated and its efficacy was studied. An untreated check was also maintained. The experiment was laid out in RBD, with three replications. The insecticidal sprays were given at ETL. The nymphal and adult populations of T. tabaci were recorded on ten plants selected at random per sub plot at 1, 3, 7, 10 and 15 days after spraying (DAS). In each plant three leaves, one each from top, middle and bottom strata were observed and mean per leaf was calculated.

\section{RESULTS AND DISCUSSIONS}

Influence of insecticidal sprays on the incidence of thrips, T. tabaci, was realized among the treatments (Table 1). Significant differences among the periods of observation were evident. Interaction between the treatment and periods of observation was also significant. Overall mean over two periods of observation clearly shows that, profenofos 50EC @ $625 \mathrm{~g}$ a.i was the most effective insecticide (1.65/3 leaves), with 57.40 per cent reduction in thrips population, compared to the mean of untreated check (3.89/3 leaves). Profenofos 50 EC having 500g a.i and 375g a.i @ 2ml each were the next best treatment, with a reduction of 52.6 and 33.3 percent in thrips population, respectively. Lambda cyhalothrin 2.5 EC @ 1ml/lit and fipronil 5 SC @ 3ml/lit were at par and were able to reduce the population of thrips by 49.6 per cent.

\section{REFERENCES}

1. Directorate of Onion and garlic research. Retrieved from http://www.dogr.res.in/index.php?option=com_content\&view=article \&id=94\&Itemid=98\&lang=en...ICAR

2. Montano, J. D. et al. (2011). Onion thrips (Thysanoptera: Thripidae): A global pest of increasing concern in onion. Journal of Economic Entomology. 104(1):1-13.

3. Sathyan, T. et al. (2016). Efficacy of synthetic insecticides against sucking insect pests in cotton, Gossypium hirsutum L. International Journal of Entomology Research. Volume 1; Issue 1; Page No. 16-21

4. Retrieved from http://apeda.gov.in/agriexchange/market\%20profile/one/onion.aspx (Indian Horticulture database)

\section{APPENDICES}

Table 1: Evaluation of Insecticides against Onion Thrips, T. Tabaci

\begin{tabular}{|c|c|c|c|c|c|c|c|c|}
\hline \multirow[t]{2}{*}{ Treatment } & \multirow{2}{*}{$\begin{array}{l}\text { Dose } \\
\left(\text { lit }^{-1}\right)\end{array}$} & \multicolumn{6}{|c|}{$\begin{array}{c}\text { Thrips Population (No./ } 3 \text { Leaves) } \\
\text { Days After Spraying }\end{array}$} & \multirow{2}{*}{$\begin{array}{l}(+) /(-) \text { Over } \\
\text { Untreated } \\
\text { Control }(\%)\end{array}$} \\
\hline & & 1 & 3 & 7 & 10 & 15 & Mean & \\
\hline Profenofos 50EC @ 375 g. a.i & $2 \mathrm{ml}$ & 2.946 & 2.385 & 2.380 & 2.373 & 2.875 & 2.5910 & -33.393 \\
\hline Profenofos 50EC @ 500 g.a.i & $2 \mathrm{ml}$ & 1.912 & 1.760 & 1.850 & 1.631 & 2.064 & 1.8430 & -52.622 \\
\hline Profenofos 50EC @625 g.a.i & $2 \mathrm{ml}$ & 1.751 & 1.525 & 1.524 & 1.505 & 1.981 & 1.6572 & -57.403 \\
\hline $\begin{array}{l}\text { Lambda Cyhalothrin 2.5 EC @ } 15 \\
\text { g.a.i }\end{array}$ & $1 \mathrm{ml}$ & 2.041 & 1.849 & 1.852 & 1.816 & 2.236 & 1.9588 & -49.665 \\
\hline Fipronil 5SC @ 50 g.a.i & $3 \mathrm{ml}$ & 2.041 & 1.849 & 1.852 & 1.816 & 2.236 & 1.9588 & -49.665 \\
\hline Quinalphos 25EC @ $300 \mathrm{~g}$ a.i. & $2 \mathrm{ml}$ & 2.406 & 2.167 & 2.257 & 2.211 & 2.606 & 2.2574 & -41.979 \\
\hline
\end{tabular}




\begin{tabular}{|l|l|l|l|l|l|l|l|l|}
\hline Untreated control & --- & 4.002 & 3.808 & 3.831 & 3.545 & 4.265 & 3.8900 & ---- \\
\hline Mean & ---- & 2.442 & 2.191 & 2.220 & 2.128 & 2.609 & 2.3180 & \\
\hline
\end{tabular}


